\title{
PERANCANGAN TEMPAT BELAJAR DI TANJUNG DUREN DENGAN PENDEKATAN OPEN ARCHITECTURE SEBAGAI RUANG KETIGA
}

\author{
Harisno Coandy Wibowo, Doddy Yuono
}

\author{
1) Program Studi S1 Arsitektur, Fakultas Teknik, Universitas Tarumanagara, harisnow.ta@stu.untar.ac.id \\ 2) Program Studi S1 Arsitektur, Fakultas Teknik, Universitas Tarumanagara, masdoddyyuono@gmail.com
}

\begin{abstract}
Abstrak
Kehidupan Jakarta yang monoton antara rumah/tempat pertama dan tempat kerja/ tempat kedua membutuhkan wadah untuk kita keluar dari rutinitas tersebut. Maka dari itu tempat ketiga (third place) hadir menjadi salah satu alternatif untuk menghilangkan kejenuhan yang ditimbulkan Jakarta. Third place yang baik adalah third place yang dapat memberikan dampak positif bagi penggunanya. Kebutuhan akan sarana belajar yang terbatas pada sekolah-sekolah mengakibatkan siswa merasa jenuh dan mencari tempat belajar lain. Oleh karena itu proyek yang diambil adalah sebuah wadah sosial berupa tempat belajar bagi siswa dan masyarakat. Tempat belajar ini tentunya akan menjadi wadah bagi siswa untuk belajar dan ruang bagi masyarakat untuk bersantai ataupun melakukan dialog sampai pelatihan. Pendekatan proyek ini ialah sharing dimana masyarakat dari berbagai kalangan dapat saling berbagi pengetahuan, sehingga masyarakat memperoleh ilmu bukan dengan cara membaca, tetapi dengan cara berdialog. Dalam perancangannya proyek ini perancang menelisik kembali apa yang dimaksudkan dengan "belajar". Proyek ini membawa segala macam metode belajar yang kita kenal menjadi satu kesatuan. Belajar tidak harus dengan membaca buku, belajar dapat dilakukan dengan berdialog sambil makan santai. Belajar tidak harus duduk di depan meja, belajar dapat dilakukan dengan berjalan. Belajar tidak harus dengan "aman", belajar dapat dilakukan dengan memberikan rasa bahaya. Dengan hadirnya bangunan ini diharapkan dapat meningkatkan kualitas hidup masyarakat terutama dalam hal pendidikan di wilayah Tanjung Duren dan sekitarnya. Sehingga menciptakan kehidupan bernegara yang lebih baik dari sebelumnya.
\end{abstract}

\section{Kata kunci: berbagi; dialog; tempat belajar}

\begin{abstract}
Jakarta's monotonous life between home/first place and workplace/ second place needs a place for us to get out of this routine. Therefore the third place comes as an alternative to eliminate the boredom caused by Jakarta. A good third place is a third place that can have a positive impact on users. The need for limited learning tools in schools results in students feeling bored and looking for other places to learn. Therefore the project taken is a social forum in the form of a place of learning for students an the community. This place of learning will certainly be a place for students to learn and space for the community to relax or conduct dialogues until training. The approach of this project is sharing where people from various groups can share knowledge, so that people gain knowledge not by reading, but by dialogue. In designing this project the designer re-examines what is meant by "learning". This project brings all kinds of learning methods that we know into a single unit. Learning does not have to be by reading book, learning can be done by dialogue while eating relaxed. Learning does not have to sit in front of a desk, learning can be done by walking. Learning does not have to be "safe", learning can be done by giving a sense of danger. The presence of this building is expected to improve the quality of life of the community, especially in terms of education in the Tanjung Duren and surrounding areas. Thus creating a better state life than before.
\end{abstract}

Keywords: dialogue; learning space; sharing 


\section{PENDAHULUAN}

Jakarta sebagai kota metropolis memiliki daya tarik tersendiri, mulai dari kemudahan hidup hingga masalahnya. Kehidupan Jakarta yang monoton antara rumah dan tempat kerja membutuhkan wadah untuk kita keluar dari rutinitas tersebut. Maka dari itu tempat ketiga (third place) hadir menjadi salah satu alternatif untuk menghilangkan kejenuhan yang ditimbulkan Jakarta. Tempat ketiga yang baik adalah tempat yang dapat memberikan dampak positif bagi penggunanya. Kebutuhan akan sarana belajar yang terbatas pada sekolah-sekolah mengakibatkan siswa merasa jenuh dan mencari tempat belajar yang tidak seharusnya seperti restaurant dan kafe. Masalah-masalah yang ada pada masa globalisasi saat ini seperti perbedaan pendapat dan sebagainya dapat diselesaikan dengan berdialog. Hal tersebut kadang terjadi karena ketimpangan ilmu yang dimiliki oleh setiap orang.

Maka dari itu usulan proyek yang penulis ajukan adalah Tempat Belajar. Tempat ini tentunya akan menjadi wadah bagi siswa untuk belajar dan ruang bagi masyarakat berdialog untuk menambah wawasan ataupun melakukan pelatihan. Pendekatan proyek ini ialah sharing dimana masyarakat dari berbagai kalangan dapat saling bertemu dan berbagi pengetahuan, sehingga masyarakat memperoleh ilmu bukan hanya dengan cara membaca, tetapi dengan cara berdialog.

\section{KAJIAN LITERATUR}

Dalam buku "Sharing Cities" karya Duncan McLaren dan Juliam Agyeman (2015) disebutkan bahwa sharing dapat dihadirkan dalam bentuk komersial. Perancangan infrastruktur, pelayanan, insentif, dan regulasi merupakan faktor penunjang terbentuknya open city. Tempat ketiga tersebut hadir untuk menghidupkan lingkungan sekitar dan menaungi komunitas tertentu. Fungsi lainnya adalah untuk menciptakan suasana baru dari kejenuhan saat ini yaitu tempat pertama/ first place (rumah) dan tempat kedua/ second place (tempat kerja/ sekolah). Sebagai contoh co-working dan street food yang pada umumnya terletak dekat dengan sistem TOD (Transit Oriented Development) pada suatu kota.

Dalam buku yang ditulis oleh Richard Florida (2014) "The Rise of the Creative Class" disebutkan bahwa untuk menciptakan komunitas kreatif yang baik diperlukan 3T; Teknologi, talenta, dan toleransi. Teknologi merupakan hal yang penting untuk melakukan riset dan membentuk teknologi baru. Talenta yang dimiliki setiap orang merupakan dorongan bagi sebuah perusahaan untuk bergerak maju menghasilkan suatu inovasi. Toleransi membantu terciptanya suasana yang baik antara anggota kelas kreatif. Dalam buku "The Image of The City" yang ditulis oleh Kevin Lynch (1960) disebutkan bahwa terdapat 5 elemen yang membentuk peta di masyarakat. Dan 5 elemen tersebut ialah 1. Jalan/ Paths: rute dimana orang bergerak, 2. Tepi/ Edges: batas tempat untuk beristirahat dalam kontinuitas, 3. Distrik/ Districts: daerah yang ditandai dengan karakteristik umum, 4. Simpul/ Nodes: titik fokus strategis untuk orientasi seperti kotak dan persimpangan, 5. Tengara/ Landmarks: titik orientasi eksternal, biasanya merupakan objek fisik yang mudah diidentifikasi dalam lingkungan perkotaan.

Dalam bukunya Hamid Shirvani (1985) "Urban Design Process" disebutkan ada 4 kelompok ruang yang saling terkait yaitu pola internal (jaringan jalan), bentuk eksternal (gambaran lingkungan dan identitas lingkungan), sirkulasi dan parkir (kualitas pejalan kaki yang aman dan pergerakan kendaraan), dan kualitas lingkungan (segala sesuatu yang berkaitan dengan kondisi sekitar seperti alam, pemandangan, dan pemeliharaan). Sedangkan menurut Diana G.Oblinger (2006) "Learning Spaces" disebutkan bahwa ruang belajar berfokus pada bagaimana ekspektasi pelajar mempengaruhi ruang, prinsip dan aktivitas yang memfasilitasi pembelajaran, serta peran teknologi yang menciptakan lingkungan belajar.

\section{METODE}

Metode yang digunakan dalam perancangan proyek Tempat Belajar di Tanjung Duren adalah melalui proses observasi kawasan dan analisis. Pada metode ini dilakukan pengamatan lokasi daerah yang diobservasi. Dengan melakukan pengamatan kita dapat melihat berbagai aktivitas 
dan fenomena yang terjadi pada daerah tersebut sehingga memperoleh hasil observasi yang kolektif.

Wilayah yang diobservasi adalah Kecamatan Grogol Petamburan, Kelurahan Tanjung Duren Utara, Jakarta Barat. Tepatnya di Jalan Tanjung Duren Raya. Analisis yang dilakukan berupa analisis makro dan mikro. Beberapa analisis yang dilakukan adalah sebagai berikut: analisis radius pejalan kaki, analisis zonasi dan fungsi sekitar tapak, analisis sistem transportasi umum, analisis titik sekolah, analisis kepadatan jalan, analisis hirarki jalan, analisis bangunan sekitar tapak, analisis jalur pedestrian pada sekitar tapak, analisis kebisingan, dan analisis view.

\section{DISKUSI DAN HASIL}

\section{Konsep Perancangan}

Dalam proses perancangannya perancang dituntut untuk menciptakan ruang ketiga bagi masyarakatnya. Dan perancang menaggapi hal tersebut dengan melihat situasi kawasan yang ada, kawasan Tanjung Duren ini membutuhkan suatu fungsi sosial yang dapat menampung segala hal kegiatan yang ada khususnya belajar. Belajar menjadi suatu hal yang jadi istimewa dalam perkembangannya. Belajar menjadi titik balik perubahan bagi suatu masyarakat. Namun hal yang ditemukan saat melakukan observasi ialah kurangnya fasilitas yang disediakan oleh pemerintah untuk menampung hal proses belajar. Oleh karena itu perancang menitikberatkan menciptakan suatu hal yang baru bagi kawasan Tanjung Duren.

Perancang melihat dibutuhkannya wadah belajar sebagai ruang ketiga bagi pelajar, dan dilain sisi perancang juga menyadari bahwa adanya masalah yang terjadi dimasyarakat seperti ketimpangan ilmu dan penguasaan emosi sehingga terjadi konflik-konflik yang tidak penting dan merugikan masyarakat lainnya (Gambar 1). Maka dari itu, perancang menyisipkan ruang publik untuk memfasilitasi proses diskusi antar individu sehingga memperkaya ilmu pengetahuan yang dimiliki setiap individu. Sehingga diharapkan dari hadirnya bangunan tersebut dapat mencerdaskan kehidupan masyarakatnya yang dimana setiap individu dapat saling menghargai pemikiran individu lainnya.

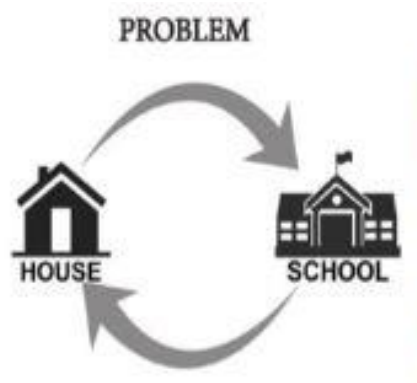

SISWA

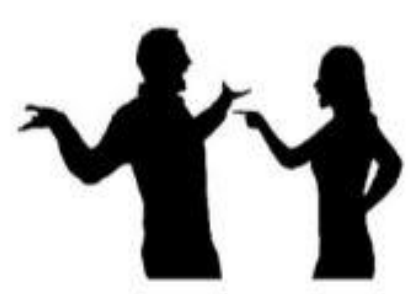

MASYARAKAT
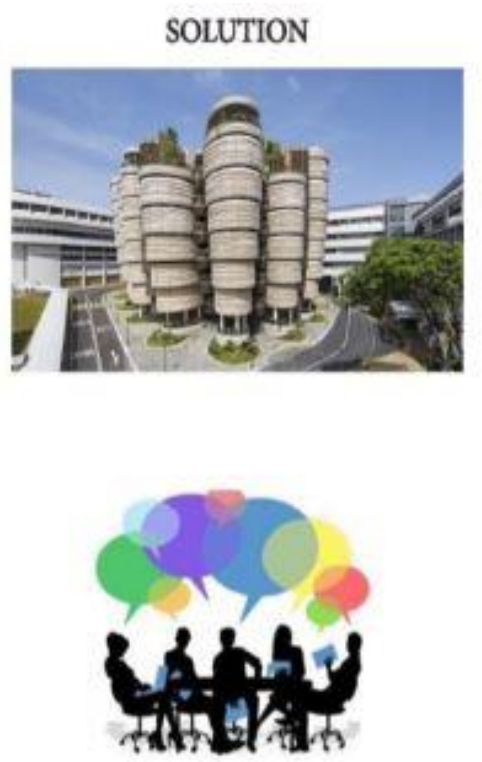

Gambar 1. Masalah Kawasan

Sumber: Penulis, 2019
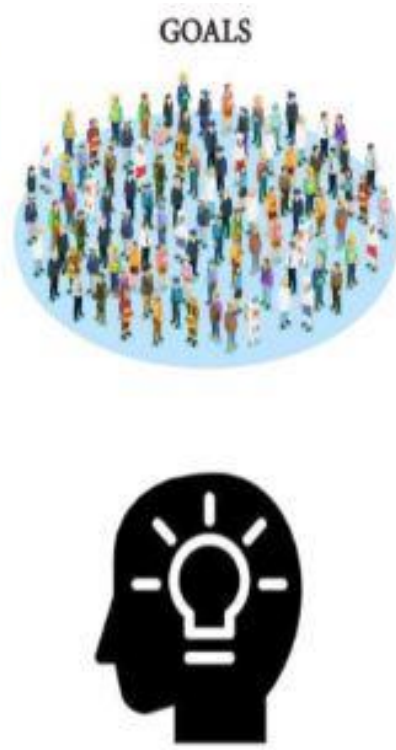

Perancangan proyek menggunakan konsep walkable building, yang dimana konsep tersebut lebih mengutamakan kenyamanan pejalan kaki dibandingkan pergerakan kendaraan di dalam tapak. Hal ini didasarkan beberapa alasan, yaitu: 
a. Lokasi tapak yang strategis menjadikan tapak sebagai titik perpindahan moda transportasi umum.

b. Ruang terbuka publik dan fasilitas untuk pendidikan yang kurang pada daerah sekitar tapak.

c. Dalam metode belajar seseorang, salah satunya terdapat belajar dengan gerak, sehingga membuat pemakai dapat berjalan mengelilingi bangunan sekaligus menghilangkan kejenuhan yang terjadi.

Dari alasan-alasan tersebut, maka digunakan sistem walkable building dalam proyek Learning Space di Tanjung Duren ini. Selain itu konsep tersebut diimbangi dengan adanya penghijauan dan pepohonan yang berfungsi sebagai peneduh dan view bagi bangunan.

Konsep walkable building tersebut diaplikasikan dalam desain dengan membuka 3 titik akses bagi pejalan kaki pada setiap jalan dan menciptakan drop off bagi transportasi umum dikarenakan bangunan ini akan menunjang akses bagi pejalan kaki kawasan tersebut (di jalan arjuna utara). Selain itu Learning Space ini tidak hanya mengandalkan sistem belajar di dalam ruangan saja, tetapi juga menggabungkan sistem belajar di luar ruangan untuk menciptakan pengalaman ruang yang menarik bagi penggunanya.

Dalam proses perancangan, perancang juga menyadari pentingnya sebuah komunitas bagi seorang pelajar. Dari individu mereka akan menciptakan sebuah tim atau grup dalam belajar untuk berbagi ilmu antar individunya, lalu dari tim yang ada akan berkembang menjadi sebuah komunitas yang lebih besar. Tentu hal tersebut membutuhkan wadah yang cukup pula untuk menampung komunitas tersebut. Jika perancang meletakkan penunjang bagi wadah tersebut di tengah maka akan mengakibatkan meluasnya wadah tersebut. Maka dari itu perancang membuat "penunjang" tersebut di bawahnya sehingga tercipta konsentrasi bagi para pelajar.

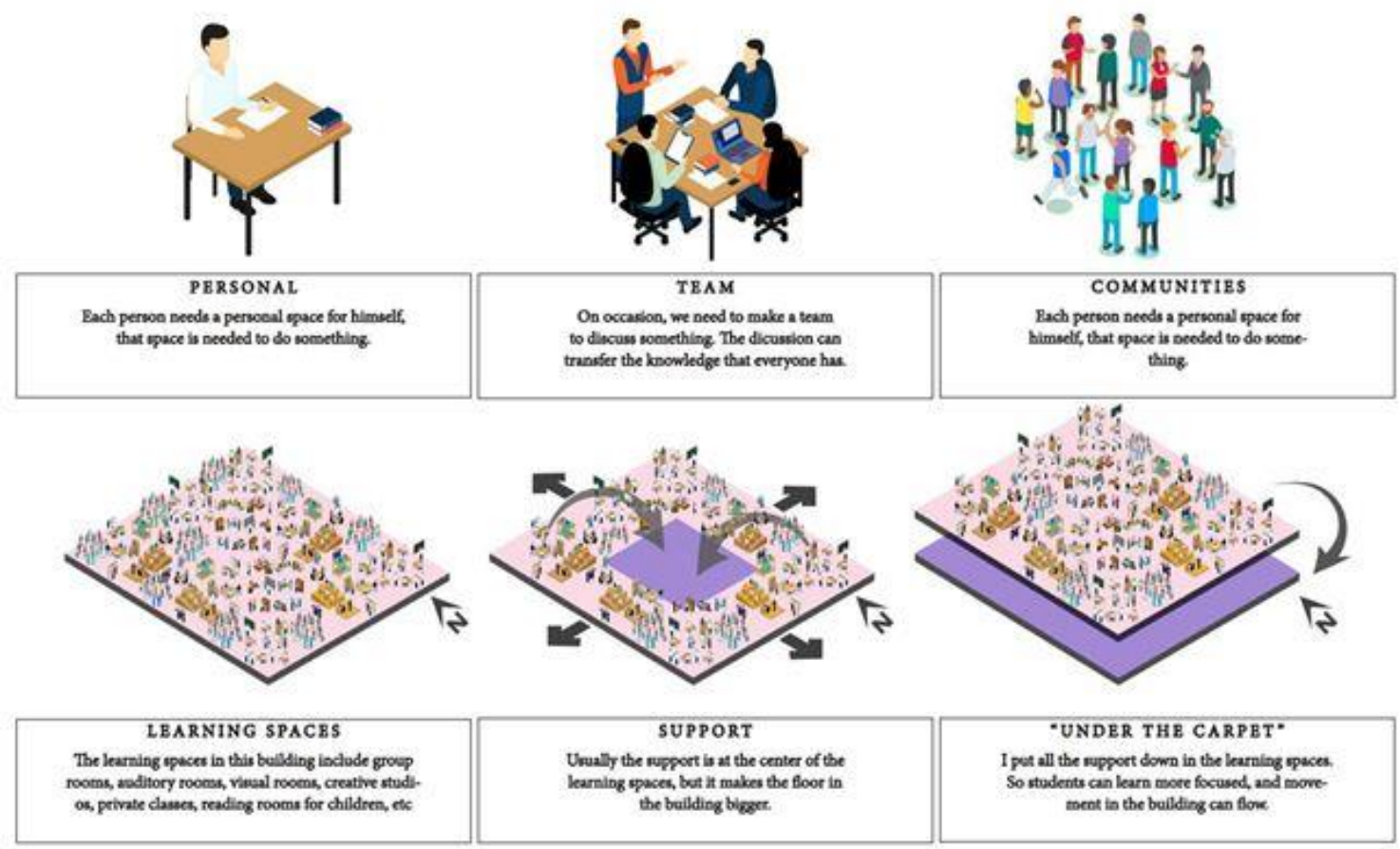

Gambar 2. Ide Konsep

Sumber: Penulis, 2019

Dalam proses pembentukan massa bangunan, perancang menggunakan beberapa strategi desain diantaranya: cross ventilation, split level, dan vertical zone (Gambar 3). Untuk menciptakan cross ventilation yang baik perancang menciptakan massa bangunan yang tipis dan banyak bukaan pada setiap lantainya. Split level digunakan untuk menciptakan pengalaman ruang yang menarik pagi pengguna dengan menaikan ataupun menurunkan lantai bangunan 
sebesar 54 centimeter. Dan vertical zone digunakan untuk menciptakan massa bangunan yang terstruktur berdasarkan zoningnya sehingga konsentrasi penggunaan lantai tidak terganggu. Selain strategi tersebut, massa bangunan tercipta dengan mengikuti bentuk tapak itu sendiri. Dengan pembagian zona yang jelas dan memperhitungkan pergerakan manusia dalam tapak itu sendiri.

\section{STRATEGI DESAIN}

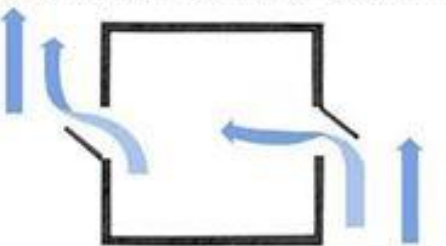

CROSS VENTILATION

Membuat massa bangunan yang tipis untuk

mencapai sirkulasi udara yang baik di dalam

bangunan.

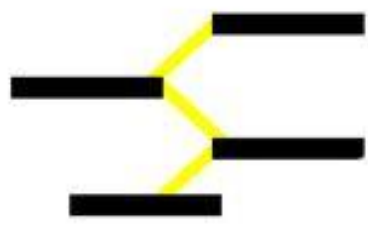

SPLIT LEVEL

Split level dipilih untuk menciptakan sirkulasi

ruang yang menarik sehingga terciptanya

estetika ruang arsitektur yang baik.

VERTICAL ZONE

Pembagian zoning program ruang dari publik ke privat secara vertikal agar sarana belajar siswa

menjadi fokus.

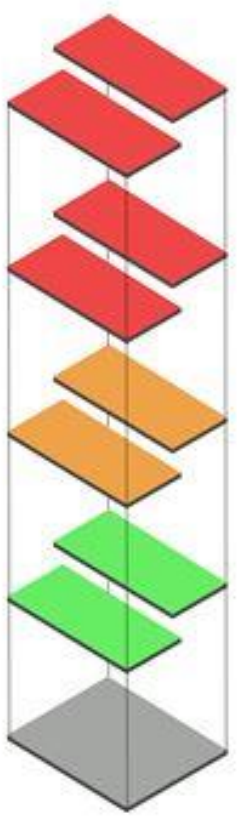

Gambar 3. Strategi Desain

Sumber: Penulis, 2019

\section{Analisa Kawasan}

Adapun beberapa analisis yang dilakukan perancang untuk menghasilkan suatu bangunan yang optimal dalam perancangan sehingga dapat menjadi sebuah tempat yang dapat memenuhi kebutuhan serta memfasilitasi masyarakatnya. Analisis yang dilakukan oleh perancang diantaranya adalah titik sekolah dan universitas disekitar tapak, analisis rencana detail tata ruang (RDTR), massing pada kawasan sekitar tapak, radius pejalan kaki, jalur transportasi publik, hierarki jalan, dan titik angkut transportasi publik pada kawasan. Posisi jalan raya, kondisi trotoar pejalan kaki, view, dan titik kebisingan pun diperhitungkan dalam hal merancang agar tidak memperparah kondisi kawasan yang ada sebelumnya. 


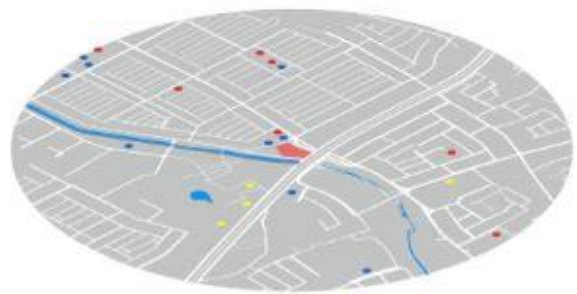

\section{EXPLODED ANALISIS KAWASAN}

TITIK SEKOLAH \& UNIVERSITAS

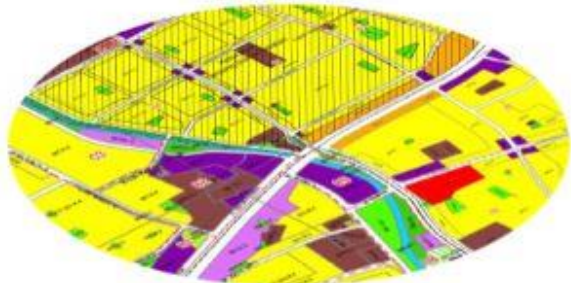

RDTR

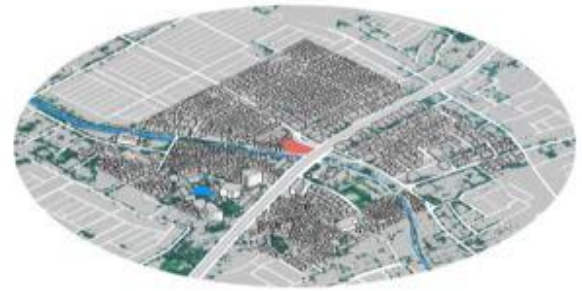

MASSING SEKITAR TAPAK

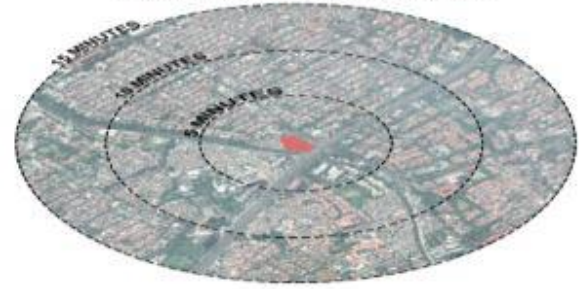

RADIUS PEJALAN KAKI
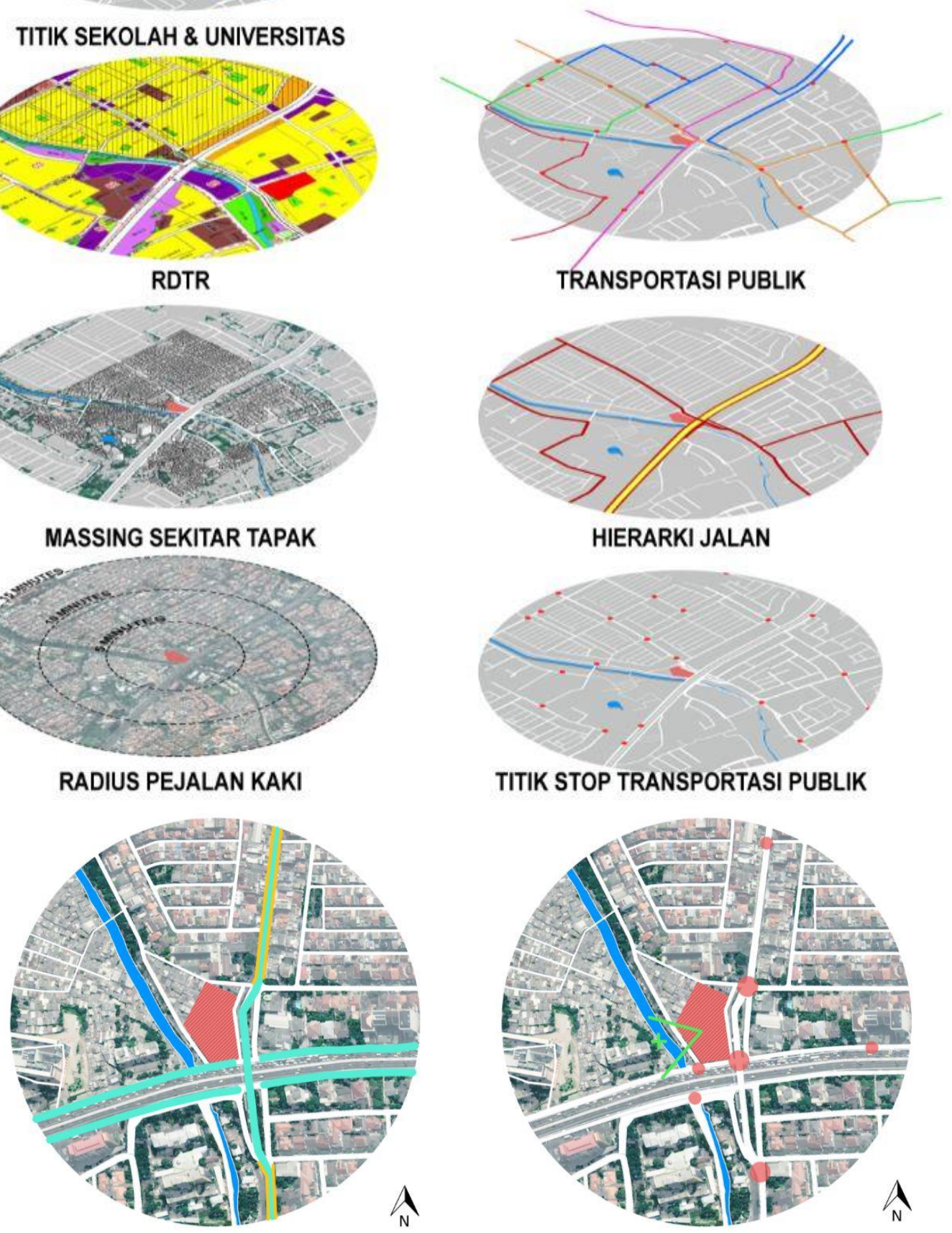

Gambar 4. Analisis Kawasan

Sumber: Penulis, 2019 


\section{Program Ruang}

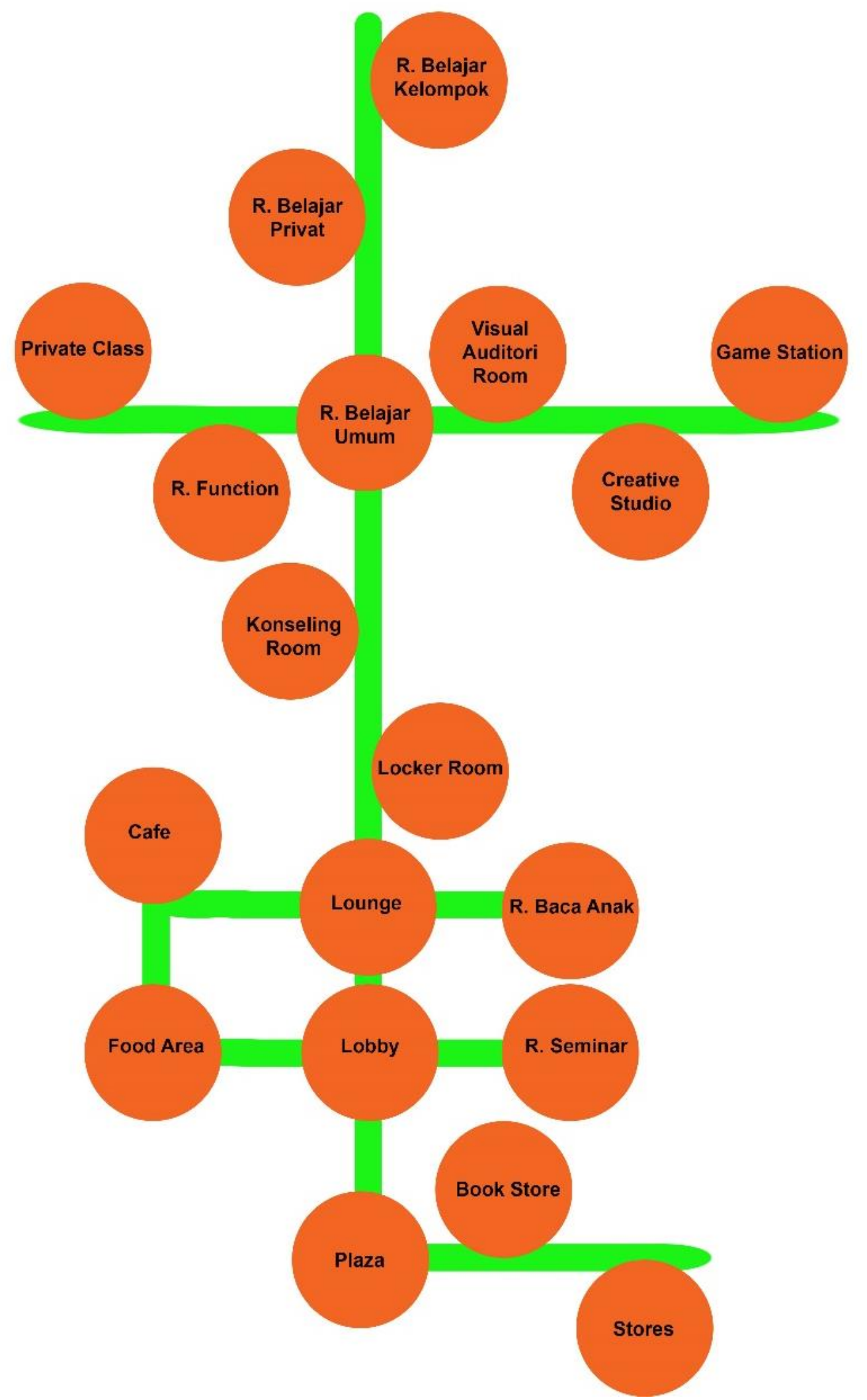

Gambar 5. Hubungan Antar Ruang

Sumber: Penulis, 2019 
Tabel 1. Perhitungan Luasan Program

\begin{tabular}{|c|c|c|c|c|c|c|}
\hline NO & NAMA RUANG & JUMLAH & KAPASITAS & STANDAR & SUMBER & LUAS (M2) \\
\hline & LANTAI DASAR & & & & & \\
\hline 1 & LOSBY \& GALERI & 1 & 150 & $2 \mathrm{M} / \mathrm{O}$ ORANG & $A D$ & 400 \\
\hline 2 & BOOK STORE & 1 & 30 & 2 M2/ ORANG & $A D$ & 72 \\
\hline 3 & WFORMATION CENTER & 1 & 10 & $2 \mathrm{M} 2 /$ ORANG & $A D$ & 40 \\
\hline 4 & GUDANG & 1 & & $2 \mathrm{MZ} / \mathrm{ORANG}$ & $A D$ & 75 \\
\hline 5 & R. KARYAWAN & 1 & 15 & 2 MZ/ORANG & $A D$ & 35 \\
\hline 6 & R. CCTV & 1 & 2 & & A & 8 \\
\hline 7 & R. TRAFO & 1 & & & A & 12 \\
\hline 8 & R. BAHAN BAKAR & 1 & & & A & 9 \\
\hline 9 & R. GENSET & 1 & & & $A$ & 35 \\
\hline 10 & RUANG BACA ANAK & 1 & 54 & & A & 123 \\
\hline 11 & KIDS LEARNING AREA & 1 & 100 & & A & 550 \\
\hline 12 & LAFITOR & 1 & & & A & 4 \\
\hline 13 & TOILET & 2 & & & A & 40 \\
\hline 14 & PARKIR & 1 & $6+24+50$ & & $A D$ & 544 \\
\hline \multirow[t]{3}{*}{15} & AMPHITHEATER & 1 & 100 & & A & 279 \\
\hline & & & & & & 2226 \\
\hline & IT MEZANUIN & & & & & \\
\hline 1 & KANTOR PENGEIOLA & 1 & 16 & 2 M2/ORANG & A & 138 \\
\hline 2 & R. MANAGER & 1 & 3 & 2NU ORANG & $A D$ & 12 \\
\hline 3 & R. SEKRETARIS & 1 & 3 & $2 \mathrm{M} 2 /$ ORANG & $A D$ & 12 \\
\hline 4 & TOILET \& SHOWERS & 2 & 2 & 3 M2/ RUAANG & $A D$ & 7 \\
\hline s) & BOOK STORE & 1 & 30 & $2 \mathrm{M} 2 / \mathrm{OPANG}$ & AD & 123 \\
\hline \multirow[t]{3}{*}{6} & READING ROOM CHILDRE & 1 & 40 & & A & 57 \\
\hline & & & & & & 349 \\
\hline & LANTAI 2 & & & & & \\
\hline 1 & LOCKER ROOM & 1 & & & A & 86 \\
\hline 2 & R. KONSEUNG & 2 & & $26.5 \mathrm{M} 2 /$ RUANG & A & 53 \\
\hline 3 & FUNCTION ROOM & 1 & 40 & 2M2/ ORANG & $A D$ & 80 \\
\hline 4 & PRUVATE CLASS & 2 & 80 & $2 \mathrm{MQ} / \mathrm{ORANG}$ & $\overline{A D}$ & 160 \\
\hline 5 & LOUNGE/GALERI & 1 & 90 & & $A$ & 454 \\
\hline 6 & TOILET & 2 & & & A & 30 \\
\hline 7 & A. PANEL & 1 & & & A & 6 \\
\hline s & STANO FOOD AREA & 1 & 4 & & $A$ & 80 \\
\hline 9 & FOOO AREA & 1 & 142 & & $A$ & 520 \\
\hline \multirow[t]{3}{*}{10} & Toluet & 2 & & & A & 40 \\
\hline & & & & & & 1509 \\
\hline & LANTAM & & & & & \\
\hline 1 & RESEARCH ROOM & 1 & 46 & $2 \mathrm{M} 2 / \mathrm{ORANG}$ & $A D$ & 88 \\
\hline 2 & COMPUTER LAB & 1 & 40 & $2 \mathrm{M} / \mathrm{O}$ ORANG & $A D$ & 88 \\
\hline 3 & CREATIVE STUDIO & 1 & 6 & & $A$ & 45 \\
\hline 4 & GAME STATION & 1 & 8 & & A & 45 \\
\hline s) & TOILET & 2 & & & A & 30 \\
\hline 6 & A. PANEL & 1 & & & A & 6 \\
\hline 7 & LOUNGE/ GALERI & 1 & 96 & & A & 427 \\
\hline s & OUTDOOR LEARNING & 1 & 54 & & A & 404 \\
\hline 9 & LEAHNING AREA & 1 & 53 & & $A$ & 168 \\
\hline \multirow[t]{3}{*}{10} & TOILET & 2 & & & $A$ & 40 \\
\hline & & & & & & 1341 \\
\hline & LantaIs & & & & & \\
\hline 1 & ROOF TOP GARDEN & 1 & 12 & & $A$ & 373 \\
\hline 2 & TOILT & 1 & & & A & 30 \\
\hline 3 & R. PANELL & 1 & & & $A$ & 6 \\
\hline 4 & STUDY ROOM & 1 & 87. & $2 \mathrm{M} 2 /$ ORANG & $A D$ & 177 \\
\hline s) & VISUAL AUDITOFI RODM & 1 & 40 & 2 M2/ ORANG & $A D$ & 89 \\
\hline \multirow[t]{2}{*}{6} & FOAUM & 1 & 40 & $2 \mathrm{M} 2 / \mathrm{ORANG}$ & $A D$ & 91 \\
\hline & & & & & & 766 \\
\hline
\end{tabular}

TOTAL LUAS PROGRAM $=6.191$

SIRKULASI $20 \%=1.238,2$

Sumber: Penulis, 2019

\section{Penampilan Bangunan}

Tampak dari bangunan didominasi oleh railing beton, selain itu perancang juga menyisipkan simbol hexagon yang terinspirasi dari sarang lebah sebagai bentuk kerjasama dalam sebuah tim. Bentuk hexagon ini ditransfer dalam bangunan sebagai ruang-ruang belajar dan atap pada bangunan. Bentuk hexagon yang dianut digunakan sebagai focal point sebagai atraksi dari bangunan tersebut. Bentuk hexagon mengunakan material beton setebal $200 \mathrm{~mm}$ dan ditutup dengan material bata tempel sehingga memberi kesan hangat pada bangunan. 


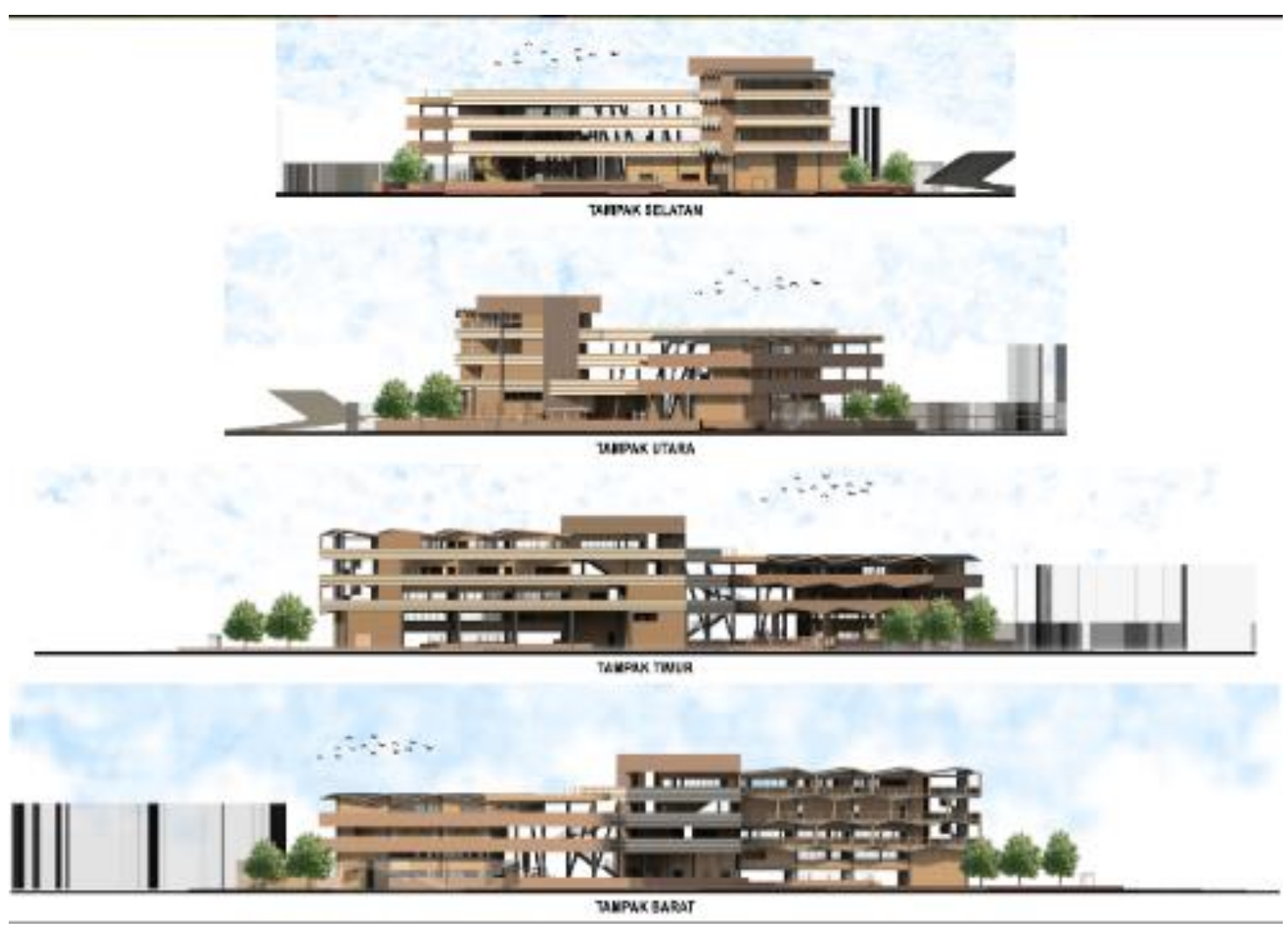

Gambar 6. Tampak Bangunan

Sumber: Penulis, 2019

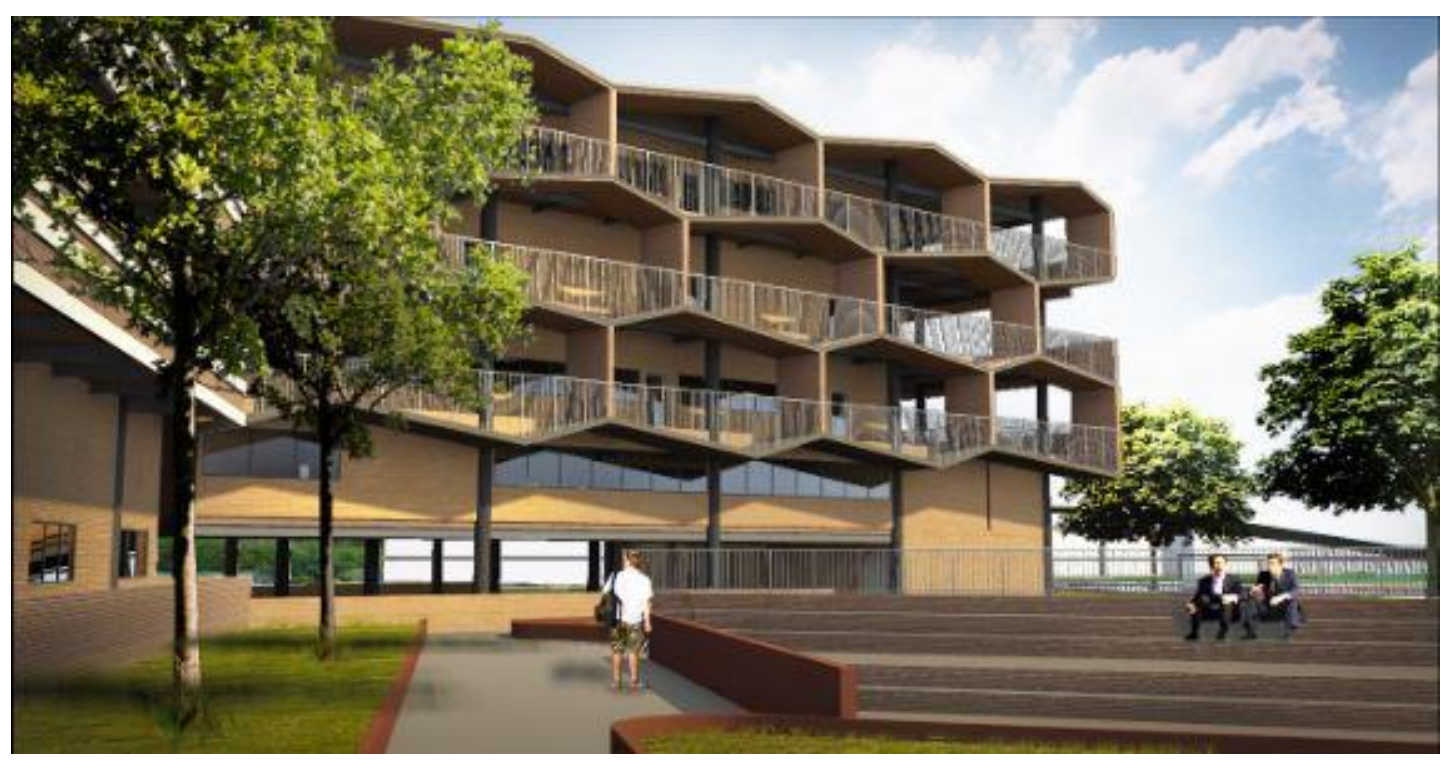

Gambar 7. Perspektif Eksterior Bangunan

Sumber: Penulis, 2019

\section{Denah dan Pembagian Ruang}

Perancangan pada proyek dilakukan dengan pembagian zonasi per lantai berdasarkan fungsi kegiatan dan hubungan antar ruang. Pada bagian lantai dasar didominasi oleh area publik seperti lobby/ galeri, toko buku, pusat informasi, area parkir, ampiteater dan ruang bermain anak yang membutuhkan pengawasan lebih dibandingkan anak SMP dan SMA. 


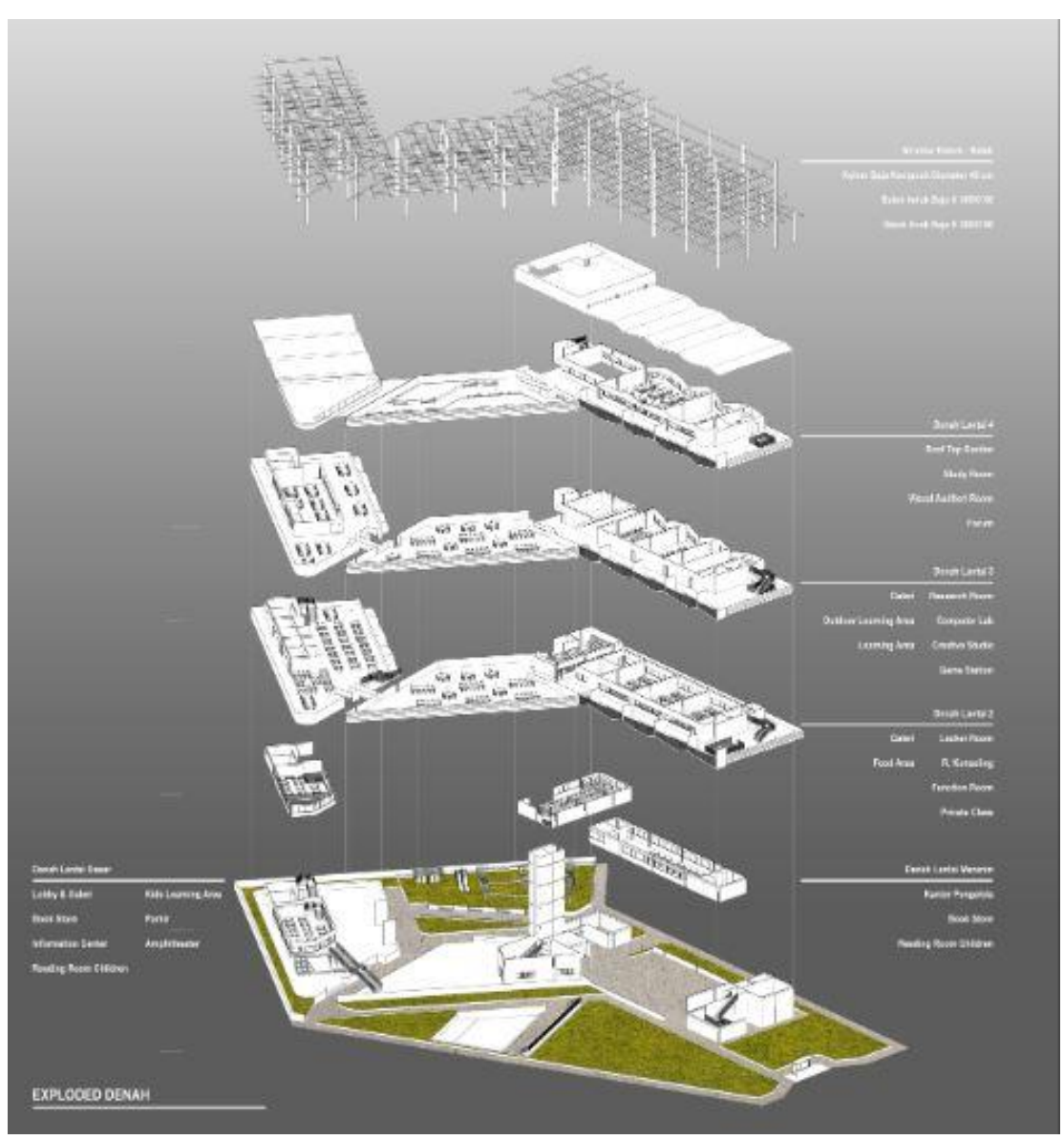

Gambar 8. Denah Axonometri

Sumber: Penulis, 2019

\section{Struktur}

Bangunan ini menggunakan struktur rangka pada bagian tubuh bangunan dan struktur space frame pada bagian atap bangunannya. Struktur pada bagian tubuh bangunan terdiri dari kolom baja komposit dan balok dengan material baja WF. Dimensi kolom komposit berdiameter 450 $\mathrm{mm}$ sedangkan untuk balok menggunakan 2 ukuran baja yang berbeda, untuk balok induk berdimensi 300×150 mm dan balok anak berdimensi 200x100 mm.

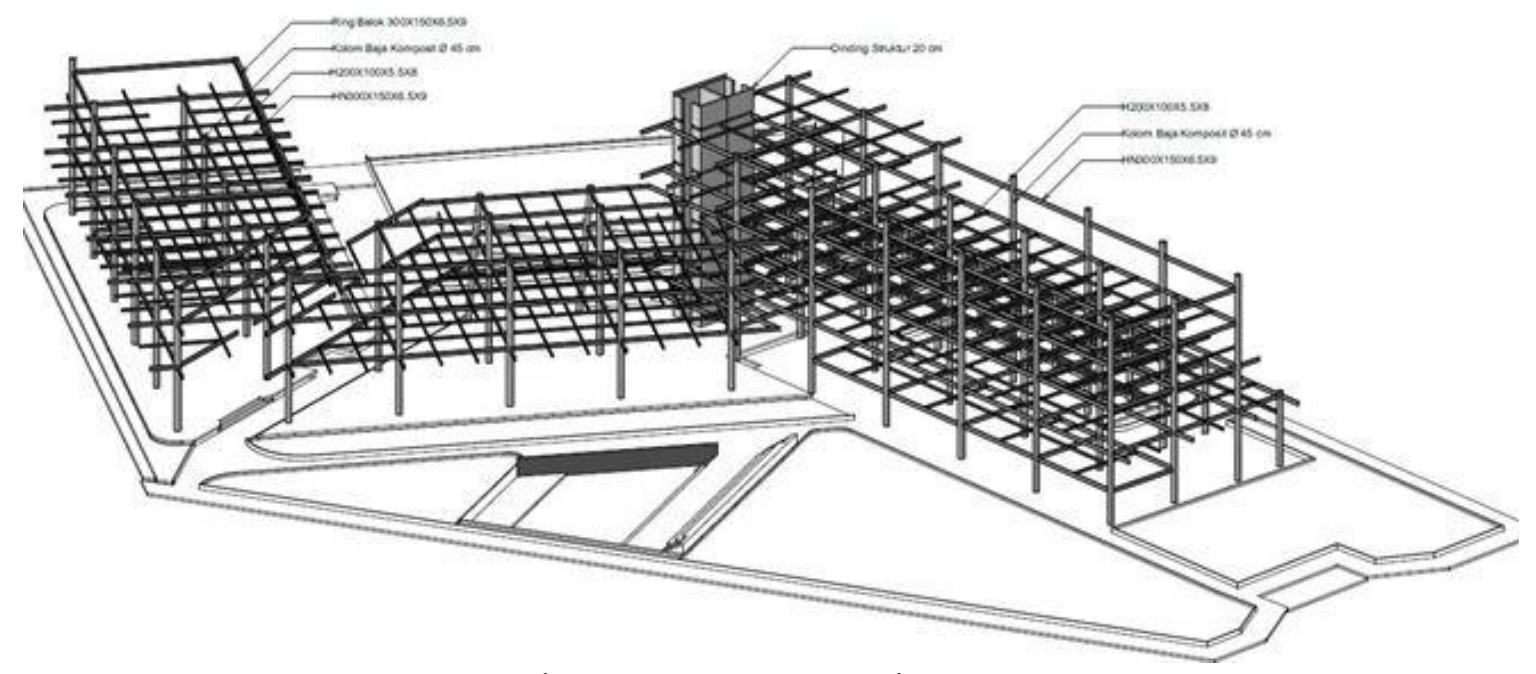

Gambar 9. Axonometri Struktur

Sumber: Penulis, 2019 


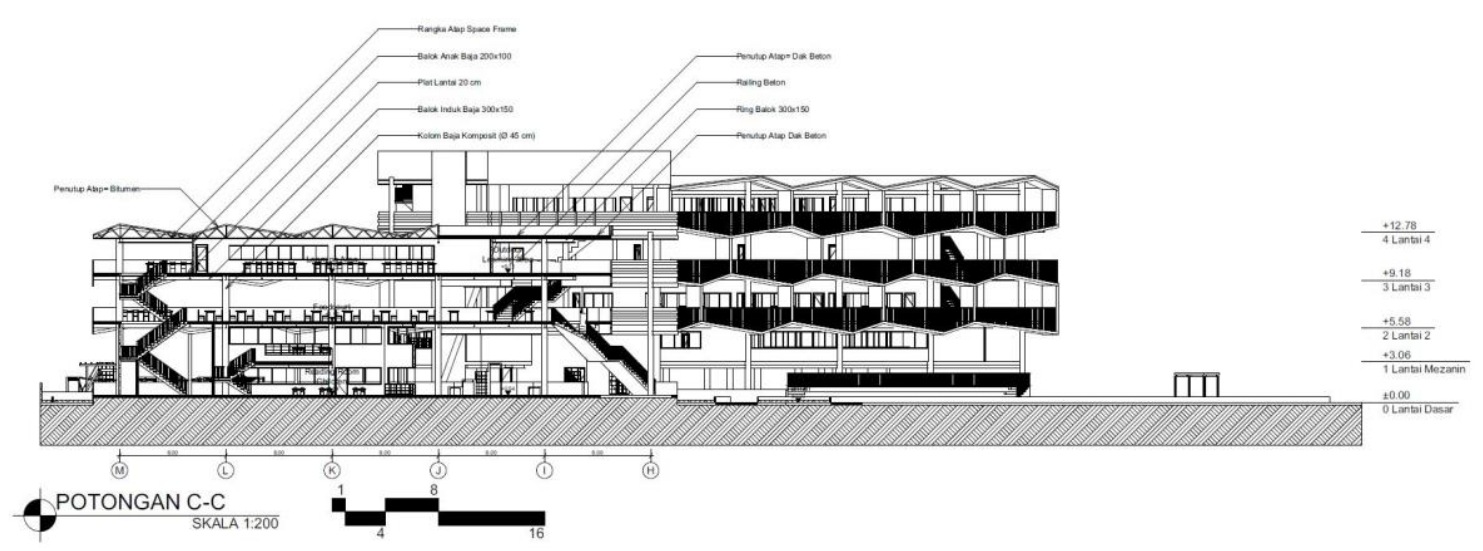

Gambar 10. Potongan Bangunan

Sumber: Penulis, 2019

\section{Mekanikal, Elektrikal dan Plumbing}

Untuk sistem utilitas pada bangunan ini terdiri dari 3 yaitu mechanical, electrical, dan plumbing. Berikut ini akan dijabarkan alur dari masing-masing sistem. Sistem mechanical dibagi menjadi 2, yaitu sistem pengudaraan dan sistem sirkulasi. Sistem pengudaraan pada bangunan menggunakan sistem AC VRV selain menggunakan sistem pengudaraan alami. Sistem sirkulasi yang digunakan menggunakan lift. Untuk diagram sirkulasi yang digunakan dapat dilihat pada bagian lampiran.

Sistem electrical menggunakan listrik yang berasal dari PLN dan Genset dalam keadaan tertentu. Listrik dari PLN tidak langsung masuk ke dalam panel listrik yang berada dalam bangunan. Listrik tersebut akan masuk ke dalam gardu PLN yang masih dalam tegangan tinggi sehingga listrik ini tidak dapat langsung digunakan. Listrik yang bertegangan tinggi akan diturunkan tegangan di dalam trafo (tegangan rendah). Setelah itu, listrik akan masuk ke dalam panel induk menuju panel cabang yang berada di masing-masing lantai untuk disebarkan ke output di setiap ruangan.

Genset yang digunakan akan aktif dalam keadaan darurat seperti mati lampu. Sistem c.o.s akan aktif sehinggan listrik dari genset akan masuk ke dalam panel genset (tegangan rendah) lalu masuk ke dalam panel induk dan ke panel cabang di masing-masing lantai. Listrik dari genset akan menghidupi output seperti lift, eskalator dan lain-lain. Diagram untuk sistem electrical dapat dilihat pada bagian lampiran

Sistem plumbing terdiri dari sistem air bersih dan sistem air kotor ( air kotor dan kotoran). SIstem air bersih menggunakan sistem down-feed yaitu menyalurkan air dari reservoir bawah (ground water tank/GWT) menuju reservoir atas. Kemudian dari reservoir atas dibagi menjadi 2 yaitu untuk keperluan sehari-hari dan keperluan darurat. Untuk keperluan sehari-hari disalurkan dari reservoir atas menuju outlet per lantai melalui shaft. Penggunaan outlet air pada proyek ini hanya terletak pada daerah toilet dan foodcourt saja. Untuk sistem air kotor terbagi menjadi air kotor dan kotoran. Air kotor berupa air hujan. Air hujan disalurkan dari atap, lantai atap dan teras melalui lubang-lubang sanitasi (floor drain). Selain itu terdapat sum-pit pada bagian ujung ramp pada lantai basement. Kemudian air hujan tersebut disalurkan langsung menuju ke water treatment plant (WTP).

Kotoran berupa limbah domestik dan limbah manusia. Kotoran per lantai disalurkan melalui shaft kotoran. Sebelum masuk ke dalam pipa induk, kotoran disaring menggunakan grease-trap yaitu penangkap lemak. Kemudian kotoran yang sudah melalui grease-trap akan disalurkan ke sewage treatment plant (STP) melalui shaft. Kotoran melalui proses filtrasi pada STP dan hasil filtrasi terbagi menjadi 2 yaitu, residu yang disalukan menuju ke riol kota dan hasil filtrasi yang diolah pada WTP. Setelah air hasil filtrasi diolah pada WTP, air dapat digunakan kembali untuk proses penyiraman tanaman . 
।

SKEMATIK DISTRIBUSI PENGUDARAAN (AC VRV)

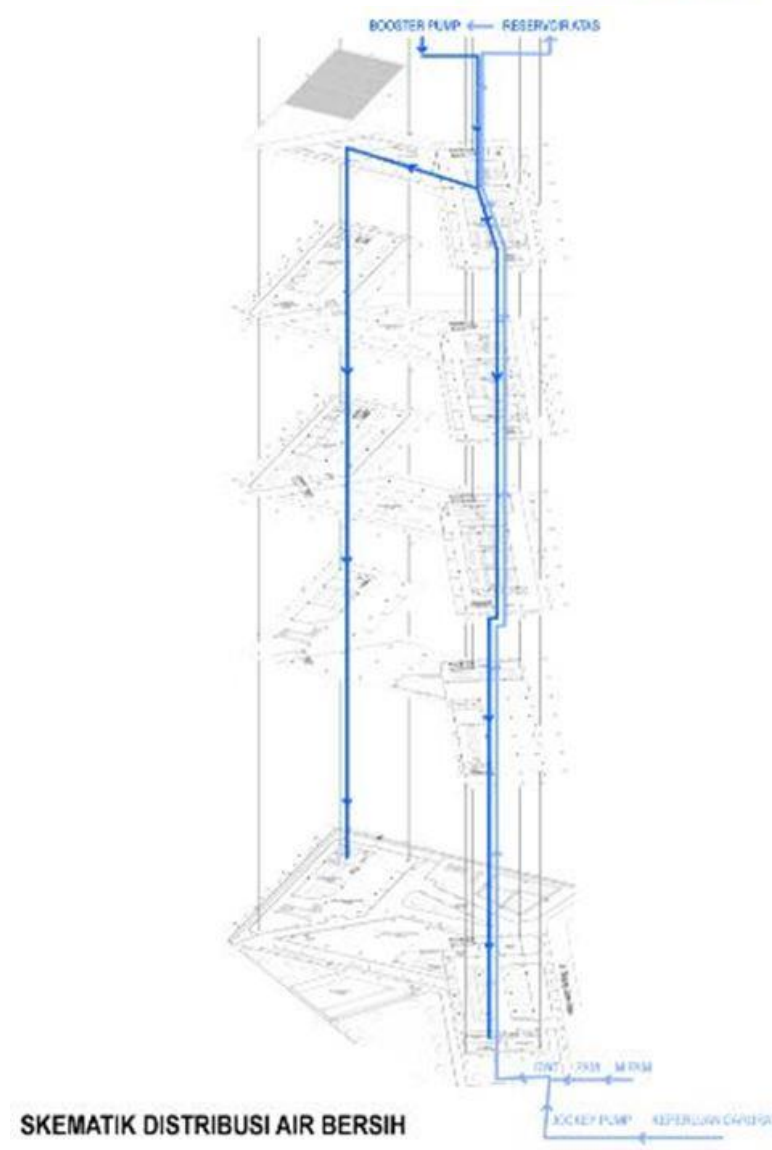

\section{SKEMATIK DISTRIBUSI LISTRIK}

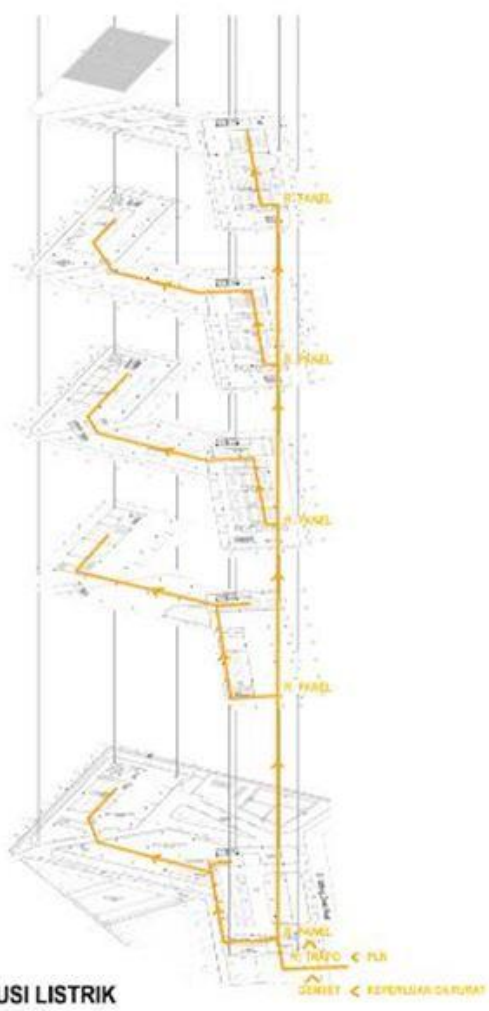

Gambar 11. Skematik Mekanikal, Elektrikal dan Plumbing Sumber: Penulis, 2019 


\section{KESIMPULAN DAN SARAN}

Dari penelitian ini dapat disimpulkan bahwa hasil bangunan yang akan dirancang merupakan bangunan fasilitas sosial yang akan mengakomodir kegiatan pembelajaran bagi setiap kalangan, khususnya pelajar. Hal tersebut dikarenakan oleh gambaran tentang wilayah Tanjung Duren merupakan kawasan bagi para pelajar. Dengan melakukan pendekatan secara open architecture yang terbuka bagi setiap kalangan, bangunan ini dirancang dengan menelisik kembali tentang apa yang dimaksud dengan kata belajar. Program ruang belajar (learning space) dan dapat juga digunakan oleh masyarakat umum untuk berdialog dengan program ruang masyarakat (public space).

Tapak bangunan yang dikelilinggi oleh tiga jalan yaitu jalan tanjung duren raya, jalan sekretaris, dan jalan arjuna utara menjadi salah satu faktor strategis dibangunnya fasilitas sosial berupa tempat belajar bagi setiap kalangan. Dengan titik yang strategis tersebut mengharuskan bangunan sebagai penanda bagi kawasan sekitar. Posisi tapak juga dapat dicapai melalui beberapa transportasi publik yang ada seperti mini trans, angkot terintegrasi jak lingko dan angkot lainnya. Dan berjarak sekitar 700 meter dari pusat kegiatan Tanjung Duren (Pasar kopro) yang dimana pada kawasan itu terdapat kantor camat, gelanggang olahraga, dll.

Dengan hadirnya bangunan ini diharapkan dapat meningkatkan kualitas hidup masyarakat terutama dalam hal pendidikan di wilayah Tanjung Duren dan sekitarnya. Sehingga menciptakan kehidupan bernegara yang lebih baik dari sebelumnya.

\section{REFERENSI}

Florida, R. (2014). The Rise of the Creative Class: And How It's Transforming Work, Leisure, Community, and Everyday Life. Basic Book

Lynch, K. (1960). The Image of the City. Massachusetts: The MIT Press

McLaren, D. dan Agyeman, J. (2015). Sharing Cities: A Case for Truly Smart and Sustainable Cities

McKinsey\&Company (2018). Skill Shift Automation And The Future Of The Workforce.

Retrieved May, 2018, from

https://www.mckinsey.com/ /media/McKinsey/Featured\%20Insights/Future\%20of\%200rg anizations/Skill\%20shift\%20Automation\%20and\%20the\%20future\%20of\%20the\%20workfo rce/MGI-Skill-Shift-Automation-and-future-of-the-workforce-May-2018.ashx

Neufert, E. (2012). Neufert Architects Data 4th Edition. Wiley Blackwell, Shirvani, H. (1985). Urban Design Process. Van Nostrand Reinhold

Oblinger. D. G.(ed) (2006). Learning Spaces. Educause 
